\title{
Współczesny język polski w oczach ludzi starszych
}

\author{
Contemporary Polish language by seniors
}

\author{
Adam ŁUCZYŃSKKI ${ }^{1}$ \\ Ateneum-Szkoła Wyższa w Gdańsku
}

\begin{abstract}
Streszczenie
Celem artykułu jest przedstawienie poglądu ludzi starszych na temat współczesnej polszczyzny i zmian w niej następujących. Materiału na potrzeby niniejszych analiz dostarczyły badania ankietowe, przeprowadzone w grupie 43 osób w wieku od 57 do 83 lat. Starsi ludzie wykazują żywe zainteresowanie tym, co się dzieje w dzisiejszej polszczyźnie, co potwierdzają zarówno same wyniki ankiety, jak również chętny udział respondentów w badaniu. Seniorzy żywo reagują na aktualne zjawiska pojawiające się w języku, są w stanie wskazać je wskazać, ocenić i skomentować.

Słowa kluczowe: gerontolingwistyka, współczesny język polski, świadomość językowa
\end{abstract}

\begin{abstract}
\footnotetext{
1 https://orcid.org/0000-0002-1595-4689

Ateneum-Szkoła Wyższa w Gdańsku

a.luczynski@ateneum.edu.pl
}

The aim of the article is to present older people's opinions on the contemporary Polish language and the changes occurring in it. The research material comes from a survey conducted in a group of 43 people aged 57 to 83 . Older people show a keen interest in what is happening in today's Polish. This is confirmed by the results of the questionnaire as well as by the willing participation of respondents in the survey. Seniors react vividly to current phenomena taking place in the language. They are able to indicate them, evaluate and offer comments on them. Keywords: gerontolinguistics, contemporary Polish language, language awareness 


\section{Wstęp}

Nadrzędnym celem niniejszego artykułu było wysondowanie opinii ludzi starszych na temat współczesnej polszczyzny i zmian w niej występujących.

Wśród prac językoznawczych podejmujących problem relacji między kompetencją językową a wiekiem najmniej jest tekstów poświęconych ludziom starszym i ich mowie. Jedyną znaną polską monografią na temat jest wydana w 1990 książka Waldemara Tłokińskiego pt. Mowa ludzi u schyłku życia (1990). Poza tym dostępne są nieliczne pozycje książkowe, artykuły czy rozdziały $\mathrm{w}$ wydawnictwach zbiorowych, w których zwraca się uwagę na specyfikę mowy ludzi starszych $\mathrm{w}$ ramach swoistego biolektu. Można tu wymienić teksty autorstwa Teresy Skubalanki $(1976)^{2}$, Aleksandra Wilkonia (2000)3 ${ }^{3}$, Moniki Zaśko-Zielińskiej (2009) czy Edwarda Łuczyńskiego (2019). ${ }^{4}$

Zagadnienie języka ludzi $\mathrm{w}$ wieku senioralnym bywa poruszane $\mathrm{w}$ pracach $\mathrm{z}$ zakresu logopedii czy niedawno wyodrębnionej jej gałęzi: gerontologopedii. Tu należy wskazać przede wszystkim pracę zbiorową pt. Gerontologopedia (red. Tłokiński, Milewski, Kaczorowska-Bray, 2018)5. Warte wspomnienia są też artykuły logopedyczne poświęcone językowi ludzi starszych, takie jak Świątek (2007) i Milewski, Kaczorowska-Bray, Kamińska (2016), a także pozycja książkowa pt. Starość - jak ją widzi logopedia (Kaczorowska-Bray, Milewski, Michalik, 2020).

Wśród wymienionych wyżej pozycji brak jednak prac, w których byłby podjęty temat stosunku ludzi starszych do języka. Niniejszy artykuł jest próbą wypełnienia tej luki. W tym celu opracowano ankietę, a następnie zebrano i przeanalizowano materiał z niej wynikający.

\footnotetext{
2 W artykule Skubalanki $(1976,261)$ pojawia się po raz pierwszy na gruncie polskim wzmianka o styku biologicznym, czyli o odmianie językowej wyodrębnionej ze względu na wiek i płeć użytkownika języka.

${ }^{3} \mathrm{O}$ odmianie języka zwanym biolektem i jej uwarunkowaniu płcią użytkownika i jego wiekiem zob. Wilkoń (2000, 103-105).

${ }^{4} \mathrm{Tu}$ między innymi czytamy o biolekcie ludzi starszych i jego cechach.

5 W ramach wymienionej pozycji Gerontologopedia (2018) warto również zaznaczyć wkład w omawianą tematykę autorów jej poszczególnych rozdziałów: Radkiewicz, Łazarewicz, WójcikTopór, Łuczyński czy Rutkiewicz-Hanczewska.
} 


\section{Wprowadzenie do przeprowadzonego badania}

Ankietę przeprowadzono wśród słuchaczy warsztatów dotyczących porozumiewania się w języku ojczystym obywających się w Ateneum-Szkole Wyższej w Gdańsku w ramach programu zdobywania i podnoszenia kompetencji dla osób powyżej 50 roku życia pt. „Pełnia talentu w pełni wieku”, który realizowany był od marca 2019 r. do stycznia 2020 r. Ankieta była anonimowa, składała się z 9 pytań o różnej formie (zamknięte i otwarte). Analizę odpowiedzi na poszczególne pytania umieszczono w dalszej części artykułu.

Respondenci biorący udział w badaniu to 43 osoby w wieku od 57 do 83 lat. Średnia wieku wyniosła 66,7 lat.

Ze względu na płeć podział respondentów wyglądał następująco:

Kobiety: 36 (83,7\%)

Mężczyźni: 5 (11,6\%)

Brak informacji o płci: 2 (4,7\%)

Średnia wieku obu płci okazałą się bardzo zbliżona (kobiety: 66,6, mężczyźni: $66,7)$.

\section{Analiza odpowiedzi na poszczególne pytania ankiety}

Pytanie nr 1: Czy interesują Panią/Pana zagadnienia związane ze współczesnym językiem polskim? (a. Tak, b. Nie, c. Trudno powiedzieć).

TAK: 35 odpowiedzi $(81,4 \%)$

NIE: 0

TRUDNO POWIEDZIEĆ: 8 (18,6\%)

Odpowiedzi TAK udzieli wszyscy mężczyźni, 29 kobiet (80,6\%) i 1 osoba bez danych o płci.

Odpowiedzi TRUDNO POWIEDZIEĆ udzieliło 7 kobiet i 1 osoba bez danych o płci.

Wniosek: Zdecydowana większość badanych deklarowała zainteresowanie współczesną polszczyzną. Nie było żadnej negatywnej odpowiedzi, a liczba osób niezdecydowanych $\mathrm{w}$ tej sprawie była niewielka. Można na podstawie tego wysnuć ogólny wniosek, iż ludzie starsi zdecydowanie interesują się tym, co się aktualnie dzieje w języku polskim. 
Pytanie nr 2: Czy zauważył/a Pan/i jakieś nowe zjawiska w języku polskim, które pojawiły się $\mathrm{w}$ ostatnich kilkudziesięciu latach? Jeśli tak, to proszę je wymienić.

Na pytanie odpowiedziały 34 osoby (79\% wszystkich respondentów).

Badani wskazali na 73 różne zjawiska (w odpowiedziach często wymieniane było więcej niż jedno zjawisko) ${ }^{6}$ :

- Wyrazy obce (zapożyczenia, wyrazy obcojęzyczne, naleciałości): 18

- Najczęściej wymieniano zapożyczenia angielskie (wyrazy/ nazwy angielskie, „zangielszczanie” języka): 12

- Skróty (uproszczenia, skrótowość, mowa na skróty): 16

- Slang młodzieżowy (język młodzieży, słownictwo młodzieżowe, język szkolny, dialekt subkultury (młodzieżowej): 7

- $\quad$ Nowe wyrazy (nowe nazwy, neologizmy): 6

- Slang internetowy (język internetowy, wirtualny, SMS-owy): 5

- Wulgarność w języku (wulgaryzmy, wulgaryzacja): 5

- Niepoprawność (błędy, niegramatyczność): 4

- Niedbałość (niechlujstwo językowe): 2

- Nowe znaczenia wyrazów (neosemantyzmy): 2

- Zanik form grzecznościowych: 2

- Zmiany w odmienności wyrazów: 1

- Polszczenie nazw obcych: 1

- Ograniczone słownictwo: 1

- Język reklamy: 1

- Zanik mowy rodzinnej (rozmów w rodzinie): 1

- Różne (niesprecyzowane) nowe zjawiska: 1.

Wnioski:

Wśród wskazanych przez respondentów dominują dwie klasy zjawisk: wyrazy obce i skróty/skrótowość (łącznie 34 wskazania, czyli 46,7\% wszystkich). Obfitość w języku polskim nazw obcych, zwłaszcza anglicyzmów, jest ogólnie zauważana przez Polaków. Ludzie starsi, dla których angielszczyzna nie jest tak bliska jak dla młodszych generacji, są zapewne szczególnie wyczuleni na to zjawisko. Interesujące jest często powtarzające się spostrzeżenie ludzi starszych, dotyczące dużej liczby skrótów i skrótowych form komunikacji we współczesnej polszczyźnie. Zarówno nadmiar wyrazów obcych, jak i skrótów

${ }^{6}$ Przedstawiane zjawiska uszeregowano od najczęściej wskazywanych przez respondentów do tych występujących w ankietach najrzadziej. 
może być dla ludzi w podeszłym wieku przeszkodą w skutecznym komunikowaniu się z otoczeniem.

Uwagę zwraca duża liczba wskazań dotyczących nowych odmian stylistycznych języka polskiego, takich jak slang młodzieżowy, slang internetowy i język reklamy (łącznie 13 wskazań, czyli 17,8\%). Na język młodego pokolenia ludzie starsi wskazują jako na zjawisko, wyraźnie różniące się od „ich” języka. Seniorzy zauważają też nowe zjawiska językowe, związane ze współczesnymi środkami komunikacji (internet, telefonia komórkowa), nieobecne w ich wcześniejszych doświadczeniach życiowych.

Wyróżniają się procentowo także wskazywane zjawiska z zakresu kultury języka, oceniane przez respondentów negatywnie, takie jak: wulgaryzacja języka, niepoprawność językowa, niedbałość, ograniczone słownictwo (łącznie 12 wskazań, czyli 16,5\%). Widać w tym przywiązanie ludzi starszych do starannej polszczyzny i wrażliwość na obniżającą się kulturę językową Polaków (zwłaszcza na zalew wulgaryzmów w debacie publicznej).

Nowe zjawiska leksykalne i semantyczne, czyli nowo pojawiające się wyrazy i ewolucje znaczeń wyrazów już funkcjonujących w języku, zostały wskazane łącznie 8 razy (11\%). Respondenci zwracali tu uwagę na nowe nazwy żeńskie (nieprecyzyjnie określane jako „odmiana nazw żeńskich” czy „końcówki żeńskie”), nowe nazwy zawodów czy też neosemantyzmy w mowie potocznej. Można na tej podstawie stwierdzić, że starsi ludzie zauważają, iż za zmianami ekonomicznymi (nowe zawody) i społecznymi (dostęp kobiet do „męskich” dotąd zawodów i stanowisk) idą też zmiany w słownictwie języka polskiego.

Interesującym wskazaniem, charakterystycznym właśnie dla ludzi starszych, jest zwrócenie uwagi na zmiany $\mathrm{w}$ języku rodzinnym, takie jak zwracanie się dzieci do rodziców na ty, a także zanik rozmów w rodzinie. W sumie były takie 3 odpowiedzi (4,1\%). Osoby starsze zauważają zmniejszający się dystans międzypokoleniowy w rodzinie, co ma odbicie we współczesnym języku, a także pewne rozluźnianie się więzów rodzinnych, co prowadzi z kolei do coraz rzadszych kontaktów językowych między członkami rodziny.

Wśród wskazań niemal brak zjawisk natury gramatycznej. Tylko jedna odpowiedź dotyczyła odmienności wyrazów, które kiedyś były nieodmienne.

Warto zauważyć, że starsi ludzie w zdecydowanej większości wskazywali ogólne zjawiska, najczęściej oceniając je negatywnie. Niewiele było konkretnych przykładów językowych, które badani podawali na poparcie swojego stanowiska. Do tych nielicznych należą: wyrazy dzięki 'dziękuję’ i nara 
'na razie' (jako przykłady skrótów), fajnie (jako przykład zapożyczenia), psycholożka i ministra (jako nowe wyrazy), dokładnie 'potwierdzam' i ciężko 'trudno' (jako nowe znaczenia), (w) radiu '(w) radio' (jako nowy sposób odmiany wyrazu) i ikonki (emotikony) zamiast wyrazów w ich pełnym zapisie.

Pytanie nr 3: Czy przypomina sobie Pan/i zjawiska językowe, które już są nieobecne we współczesnej polszczyźnie? Jeśli tak, to proszę je wymienić.

TAK: 17 odpowiedzi (39,5\% badanych), w których znalazło się 21 różnych zjawisk.

Pozostałe osoby najczęściej pozostawiły przy tym pytaniu puste miejsce w ankiecie. Niektórzy respondenci usprawiedliwiali się, pisząc: „Nie pamiętam”, „Kiedyś mnie to nie interesowało”, „Uczyłam się już współczesnego języka”.

Wskazane 21 zjawisk, nieobecnych już w dzisiejszej polszczyźnie, można pogrupować następująco:

- Dawne wyrazy (archaizmy, wyrazy archaiczne): 6 wskazań

- Dawne formy nazwisk: 5

- Zwroty grzecznościowe: 4

- Wysoka kultura językowa: 3

- Zmienione znaczenia wyrazów: 1

- Regionalizmy: 1

- Dawny rodzaj pisma: 1

Wnioski:

Zwraca uwagę znacznie mniejsza liczba odpowiedzi w porównaniu z poprzednim pytaniem. Okazuje się, że - wbrew ogólnemu przekonaniu ludzie starsi w mniejszym stopniu koncentrują się na przeszłości języka polskiego niż na współczesnej polszczyźnie. Bardziej interesuje ich to, co jest nowe dla nich (choć nie zawsze przez nich akceptowane), niż to, co już minęło. Można to uznać za bardzo racjonalną postawę życiową $\mathrm{w}$ odniesieniu do języka.

Badane osoby starsze najczęściej uznawały za nieobecne bądź zanikające zjawiska związane z kulturą językową, takie jak coraz rzadziej używane wyrazy o funkcji grzecznościowej (proszę, dziękuję) czy zwroty z użyciem słów pan lub pani. W jednej z odpowiedzi była mowa o zaniku trybu przypuszczającego $\mathrm{w}$ funkcji grzecznościowej (zwanego przez respondenta „trybem grzecznościowym”, z przykładami: chciałby, wolałby). Do tej grupy odpowiedzi można zaliczyć ogólne stwierdzenia o zaniku wypowiedzi świadczące 
o wysokiej kulturze użytkowników języka, określane przez respondentów jako „piękny język/styl”, „bez skrótów”.

Zgodnie ze społecznym wyobrażeniem badane osoby jako przykłady dawnej polszczyzny często podawały nieużywane lub używane coraz rzadziej wyrazy (nazywane przez nich też archaizmami, wyrazami archaicznymi czy wyrażeniami staropolskimi). Wśród 6 tego typu odpowiedzi pojawiło się 7 konkretnych przykładów: durszlak, kredens, podwórzec, ponoć, onegdaj, pomocnik 'szafka', kendyk (?) 'kędy'. To jedynie niewielki zbiór różnych wyrazów, przytoczony przez respondentów, trudno więc go w sposób jednoznaczny skomentować. Dodatkowo w grupie tej pojawiały się także odpowiedzi, które wskazywały jedynie w sposób ogólny na „dawne wyrazy”, nie podawały jednak żadnych konkretnych przykładów.

Kolejna grupa zjawisk wskazanych przez osoby starsze dotyczy zanikających form nazwisk. Przede wszystkim są to nazwiska żeńskie z przyrostkiem -owa (podany przykład: Nowakowa) lub -ówna (podano: Nowakówna, Królakówna, Szterkówna). Do tej grupy można włączyć odmężowskie nazwy żeńskie: doktorowa i kapitanowa. Nazwiska żeńskie ze swoistymi przyrostkami, a także odmężowskie pospolite nazwy żeńskie to niewątpliwie zjawisko przechodzące do historii języka polskiego. Poza tym niespodziewanie jedna $\mathrm{z}$ osób podała jako nieużywany typ nazwisk o zakończeniu - ewicz (bez konkretnego przykładu). Prawdopodobnie osobie tej ten tym zakończeń nazwisk skojarzył się $\mathrm{z}$ nazwiskami pochodzącymi z dawnych Kresów Wschodnich (pośrednio kojarzących się z przeszłością).

Jako pojedyncze zjawiska podawano: zmiany znaczeń wyrazów (osoba podała jako przykład wyraz komórka, znany wcześniej jako 'skład', a obecnie przede wszystkim jako 'telefon komórkowy'), występowanie regionalizmów (bez przykładów) i dawny styl pisania (zapewne chodziło o zanikającą sztukę kaligrafii).

Pytania nr 4: Jak Pan/i ocenia zmiany we współczesnej polszczyźnie? (a. Pozytywnie, b. Negatywnie, c. Nie mam zdania):

NEGATYWNIE: 21 (48,8\%)

POZYTYWNIE: 7 (16,3\%)

NIE MAM ZDANIA: 15 (34,9\%)

Wnioski:

Prawie połowa starszych ludzi zmiany we współczesnym języku polskim ocenia negatywnie. Jest to spójne z odpowiedziami na pytania nr 2 i 3 (badani 
bardzo często nowe zjawiska $\mathrm{w}$ polszczyźnie oceniali negatywnie, natomiast o zanikających częściej pisali w pozytywnym tonie).

$\mathrm{W}$ najmniej licznej grupie badanych, oceniających zmiany w języku polskim pozytywnie, średnia wieku była nieco niższa od ogólnej średniej (wynosi 65,9), co może sugerować, że osoby młodsze w ramach badanej grupy są bardziej skłonne do akceptowania nowych zjawisk językowych, natomiast $\mathrm{z}$ wiekiem rośnie liczba osób negatywnie oceniających rozwój języka.

Liczna grupa niezdecydowanych może wynikać z rzeczywistego braku zdania $\mathrm{w}$ powyższej kwestii. Może też brać się stąd, że dwa wybory w tym pytaniu (4.a. i 4.b.) wiązały się $\mathrm{z}$ ewentualnym uzasadnieniem swojego stanowiska w kolejnym punkcie ankiety, a to wiązało się z pewnym wysiłkiem, na który być może respondenci nie mieli ochoty.

Pytanie nr 5: Jeśli wybrał/a Pan/i odpowiedź a lub $b$, proszę ją uzasadnić, podając przykłady negatywnych bądź pozytywnych zmian w języku polskim.

Na pytanie nr 5 odpowiedzi udzieliło 25 osób, czyli 58,1\% badanych.

Pytanie to nawiązywało do pytania go poprzedzającego i adresowane było do tych osób, które wcześniej wybrały opcję $a$ lub $b$. Zdecydowana większość z nich udzieliła kolejnej odpowiedzi, w tym wszystkie osoby, które zmiany językowe w polszczyźnie oceniły pozytywnie, 17 (z 21) osób mających przeciwne zdania oraz jedna, która nie była zdecydowana $\mathrm{w}$ poprzednim pytaniu i wybrała bezpieczną odpowiedź „Nie mam zdania”.

W sumie badani wymienili 35 różnych czynników, które - ich zdaniem świadczą o pozytywnym lub negatywnym aspekcie zmian we współczesnym języku polskim. Zdecydowanie więcej ich było w grupie osób, które uważały, iż zmiany w naszym języku idą w złym kierunku. Wymieniono 28 takich czynników, co stanowiło $\mathbf{8 0} \%$ wszystkich odnotowanych w tym pytaniu zjawisk. Było to zgodne $\mathrm{z}$ danymi uzyskanymi $\mathrm{w}$ poprzednich pytaniach, zwłaszcza w pytaniu nr 2. Dwie osoby w odpowiedzi na pytanie 5 . zwróciły na ten fakt uwagę, odsyłając analizującego ankietę do odpowiedzi udzielonej już na pytanie 2 .

Poniżej zaprezentowano listę czynników, które zostały uznane przez badanych za te, które świadczą o negatywnym charakterze zmian w polszczyźnie:

- Niepoprawność (błędy językowe, niedbałość językowa): 6 wskazań

- Wulgaryzmy: 5

- Elementy obce: 4

- Skróty (skrótowość): 4 
- Niezrozumiałość wypowiedzi: 2

- Ubożenie słownictwa: 2

- Zanik form honoratywnych: 1

- Nazwy żeńskie: 1

- Nowe znaczenia wyrazów: 1

- Zanikanie naturalnej rozmowy: 1

- Język we wszystkich dziedzinach życia (?): 1

Osoby, które oceniły zmiany w polszczyźnie pozytywnie, wskazały 4 następujące czynniki świadczące - ich zdaniem - o tym fakcie:

- Poszerzenie zasobu słownikowego języka: 4

- Nowe formy gramatyczne: 1

- Nazwy żeńskie: 1

- Uproszczenia: 1

Wnioski:

Już odpowiedzi na poprzednie pytania wskazywały na to, że ludzie starsi $\mathrm{w}$ większości oceniają negatywnie zmiany zachodzące $\mathrm{w}$ języku polskim (objawiające się jako nowe zjawiska). Wśród nich dominują kwestie z kręgu kultury języka, takie jak niepoprawność językowa (błędy językowe, niechlujność językowa), szerzenie się wulgaryzmów, nadmierna skrótowość wypowiedzi, ich mała zrozumiałość czy coraz uboższe słownictwo w użyciu. W tej grupie znalazło się 19 czynników, czyli 67,9\% wszystkich negatywów. Widać z tego, że ludzi starszych najbardziej razi obniżająca się jakość współczesnych komunikatów językowych, prowadząca często do trudności $\mathrm{w}$ ich odbiorze. Do negatywów wśród zmian językowych polszczyzny zaliczane są też szerzące się wyrazy obce (przy jednoczesnym zaniku polskich słów) i różne naleciałości obcego pochodzenia (4 wskazania, czyli 14,3\%). Pojedynczo wymieniane były inne negatywne czynniki, takie jak zanik form honoratywnych, czyli takich, które sygnalizują szacunek $\mathrm{w}$ stosunku do rozmówcy, zanikanie naturalnych form rozmowy, pojawianie się nowych znaczeń wyrazów (prawdopodobnie zdaniem respondenta niepotrzebnych), szerzenie się żeńskich nazw zawodowych. Niekiedy odpowiedzi były niejasne, jak ta, która brzmiała: „Język we wszystkich dziedzinach życia” (ocena negatywna w najszerszym odniesieniu do użycia języka?).

Wśród odpowiedzi negatywnie oceniających nowe zjawiska w polszczyźnie rzadko pojawiały się konkretne przykłady. Odnotowano takie trzy: wymowa -om zamiast -ą $\mathrm{w}$ końcówkach wyrazów (uznana przez 
respondenta za błąd deklinacyjny), szerzenie się obcych wyrazów cafeteria i cafe-bar zamiast rodzimej nazwy kawiarnia, a także używanie zaimka ty w stosunku do starszych osób.

Z kolei seniorzy, którzy pozytywnie odnoszą się do zmian we współczesnym języku polskim, zwracają przede wszystkim uwagę na bogacenie się słownictwa, co wiąże się z postępem wiedzy i wzrastającą liczbą nowych pojęć (zwłaszcza technicznych, jak podają badani). Warto zwrócić uwagę na to, że wśród pozytywnych czynników badani wymieniają $\mathrm{w}$ ramach tej grupy powstałe zawodowe nazwy żeńskie, a także uproszczenia (prostsze formy wypowiedzi). Te same czynniki były przez innych respondentów uznawane za negatywy. Jeden $\mathrm{z}$ ankietowanych pozytywnie ocenił możliwość używania wariantywnych form gramatycznych, takich jak $w$ radio $i \quad w$ radiu.

Jedna osoba, która we wcześniejszym pytaniu wybrała odpowiedź c (czyli „Nie mam zdania”), uzasadniła to w sposób następujący: „Wszystkie odmiany nazwisk". Odpowiedź nie jest jasna i trudno ją zaklasyfikować do któregoś $\mathrm{z}$ dwóch omawianych powyżej stanowisk w kwestii oceny zmian w języku, ograniczono się więc do jej odnotowania.

Pytanie nr 6: Gdzie można, zdaniem Pani/Pana, znaleźć wzorzec języka polskiego, który jest godny naśladowania? (a. W literaturze, b. W radiu, c. W telewizji, d. W internecie, e. W kościele, d. W wypowiedziach znanych ludzi, e. Gdzie indziej, np. ...)

$\mathrm{Na}$ to pytanie odpowiedziało 41 osób (z 43). Badani wskazali 51 wzorców polszczyzny, wybierając niekiedy więcej niż jeden wzorzec i wykorzystując $\mathrm{w}$ większości zaproponowane $\mathrm{w}$ ankiecie możliwości. Po pogrupowaniu wypowiedzi wybór wzorców wyglądał następująco:

- Literatura: 29 (56,9\%)

- Kościół: 6

- Wypowiedzi znanych ludzi: 5

- Gdzie indziej: 5

- Radio: 4

- Telewizja: 1

- Internet: 1

W odpowiedzi „Gdzie indziej” wymienione zostały dwa razy słowniki (Słownik języka polskiego i Słownik poprawnej polszczyzny) oraz w pojedynczych przypadkach: prasa, spotkania literackie i kluby dyskusyjne. 
Wnioski:

W odpowiedziach na pytanie $\mathrm{nr} 6$ osoby starsze $\mathrm{w}$ zdecydowanej większości wskazały literaturę jako wzorzec polszczyzny. Pojawiło się to w odpowiedziach 31 osób (czyli 75,6\% spośród wszystkich, które udzieliły odpowiedzi na to pytanie). Oznacza to, że dla ludzi w podeszłym wieku teksty literackie są najwartościowszym źródłem poprawnej i pięknej polszczyzny. Można przypuszczać, że nie chodzi tu o jakąkolwiek literaturę (na co uwagę zwróciła jedna z osób, opatrując swoją odpowiedź komentarzem: „Zależy w jakiej”), lecz raczej o literaturę klasyczną. Takie stanowisko wiąże się $\mathrm{z}$ tradycyjnym traktowaniem języka literackiego jako wzorca starannej i wysokiej pod względem jakości polszczyzny.

Pozostałe wzorce były znacznie rzadziej wybierane w ankiecie. Pojawiający się na drugim miejscu wśród odpowiedzi kościót, choć znacznie ustępujący statystycznie literaturze (11,8 \% wszystkich wskazań), świadczy o tym, że ludzie starsi znajdują także w tym miejscu polszczyznę, którą można naśladować. Chodzi tu o język kazań, a także język odczytywanych przez księży tekstów liturgicznych. Jednocześnie można przyjąć, że dla ludzi w podeszłym wieku Kościół jest zarówno przewodnikiem w sprawach światopoglądowych i moralnych, jak i językowych.

Wyniki analizy powyższego pytania wskazują na to, że niekiedy również język pewnych osób, które dla ankietowanych są autorytetem, można wykorzystywać jako wzorzec polszczyzny (9,8 \% wskazań).

Warto zwrócić uwagę na fakt, że badane osoby starsze jako wzór do naśladowania stosunkowo rzadko wybierały język środków masowej komunikacji. W sumie pojawiło się tu 7 wskazań, z czego 4 dotyczyły radia, co świadczy o tym, że badani w sprawach językowych ten właśnie rodzaj masowego medium darzą największym zaufaniem. Telewizja, internet i prasa były wymieniane $\mathrm{w}$ tym pytaniu pojedynczo, a przy prasie znalazło się zastrzeżenie, że dotyczy to jedynie wybranych tytułów, artykułów czy autorów. Niski poziom zaufania do języka prezentowanego $\mathrm{w}$ mediach masowych ludzie starsi dzielą z rozpowszechnioną opinią, dotyczącą niskiego poziomu językowego zamieszczanych tam tekstów czy wypowiedzi.

Pytanie nr 7: Czy zna (bądź znał/a) Pan/i osobę publiczną, której język uznaje Pan/i za wzór pięknej polszczyzny? Jeśli tak, to proszę wymienić tę osobę (lub te osoby). 
$\mathrm{Na}$ to pytanie odpowiedziała pozytywnie zdecydowana większość badanych. Było to 38 osób (czyli 88,4\% ankietowanych), w tym jedna, która udzieliła odpowiedzi wymijającej, stwierdzając, iż jest wiele osób mogących uchodzić za wzór. 5 osób pozostawiło puste miejsce w polu na pytanie nr 7 bądź napisało „Nie wiem”. Wśród odpowiedzi było 71 wskazań osobowych, a wymienionych nazwisk 38.

Zdecydowanie najwięcej głosów padło na dwa nazwiska językoznawców, znanych z popularyzacji wiedzy o języku w środkach masowej komunikacji (zwłaszcza w telewizji): Jan Miodek (15 wskazań) i Jerzy Bralczyk (13). W sumie oba te nazwiska zebrały 39,4\% wszystkich głosów.

Pozostałe nazwiska wymieniane przez ankietowanych w zdecydowanej większości pojawiają się pojedynczo, wyjątkowo trzykrotnie (W. Bartoszewski), a dwukrotnie w wypadku sześciu nazwisk: A. Duda, I. Dziedzic, G. Holoubek, J. Suzin, W. Tłokiński i O. Tokarczuk. Wydaje się, że większość wymienionych w tej grupie nazwisk to przykłady osób, które są darzone ogólną sympatią przez badanych, niekoniecznie związaną z językiem przez te osoby używanym. Do tego stwierdzenia upoważnia fakt, iż najwięcej z podanych nazwisk (13 w 16 wskazaniach) jest lub była znana $\mathrm{z}$ telewizji (spikerzy, prezenterzy, dziennikarze telewizyjni, autorzy programów telewizyjnych: Irena Dziedzic, Bogusław Kaczyński, Tomasz Kamel, Lucjan Kydryński, Tomasz Lis, Krystyna Loska, Monika Olejnik, Marzena Rogalska, Tomasz Sianecki, Jan Suzin, Jerzy Wasowski, Edyta Wojtczak, Krzysztof Ziemiec). Duża liczba postaci $\mathrm{z}$ telewizyjnego ekranu kłóci się z danymi z pytania $\mathrm{nr}$ 6, w którym badani nie wskazywali telewizji (poza jednym przypadkiem) jako miejsca, gdzie można znaleźć wzorcową polszczyznę. Również w sprzeczności z pytaniem 6. jest zaledwie jedno nazwisko przedstawiciela literatury $\mathrm{w}$ omawianych odpowiedziach (chodzi o dwukrotnie wskazaną Olgę Tokarczuk), podczas gdy wśród wzorców wymienianych $\mathrm{w}$ odpowiedziach na tamto pytanie zdecydowanie najczęściej wskazywana była literatura.

Statystycznie wyróżniają się nazwiska przedstawicieli świata nauki w osobach: Władysława Bartoszewskiego, Leszka Kołakowskiego, Tadeusza Kotarbińskiego, Magdaleny Środy, Waldemara Tłokińskiego, Andrzeja Zolla (niektórzy z nich związani też z działalnością polityczną, np. W. Bartoszewski, M. Środa, A. Zoll). Pojawiło się tu 6 nazwisk w 9 wskazaniach. Również 6 nazwisk (ale w pojedynczych wskazaniach) dotyczy osób reprezentujących kler: Adam Boniecki, Sławoj Leszek Głódź, Tadeusz Gocłowski, Jan Paweł II, Jan Kaczkowski, Józef Tischner (A. Boniecki jest również związany z dziennikarstwem, a J. Tischner - z literaturą i filozofią). 5 nazwisk podanych $\mathrm{w}$ ankiecie dotyczy polityków (są to: Adam Bodnar, Marek Borowski, 
Włodzimierz Cimoszewicz, Andrzej Duda, Jan Olszewski), 3 - aktorów filmowych (Gustaw Holoubek, Jerzy Stuhr, Beata Tyszkiewicz), a w jednym przypadku - dziennikarstwa (Teresa Torańska).

Wnioski:

Wyraźne wyróżnienie przez osoby starsze profesorów Jana Miodka i Jerzego Bralczyka, językoznawców propagujących piękną i poprawną polszczyznę, a jednocześnie używających języka zgodnego ze współczesnymi normami, świadczy o tym, że respondenci trafnie wskazali osoby, którym można zaufać $\mathrm{w}$ wyborze formy językowej w swoich wypowiedziach. Wyróżnienie przedstawicieli nauki czy Kościoła przez ludzi starszych może oznaczać, że badani ufają w sprawach językowych osobom z najwyższym wykształceniem oraz $\mathrm{z}$ autorytetom kościelnym. Natomiast inne wskazania okazały się nie całkiem zgodne ze wstępnym wyobrażeniem autora ankiety. Wymienione (zwykle pojedynczo) nazwiska osób znanych z ekranu telewizyjnego, z kina czy ze sceny politycznej świadczą raczej o osobistych sympatiach ankietowanych do tych osób, a sprawa używanego przez nich języka wydaje się tu - przynajmniej w większości - drugorzędna.

Pytanie nr 8: Czy uważa Pan/i, że jest coś, co zagraża współczesnemu językowi polskiemu? Jeśli tak, to proszę podać, co to może być.

$\mathrm{Na}$ to pytanie zdecydowana większość badanych (32 osoby, czyli 74,4\%) odpowiedziała twierdząco, przytaczając 55 zjawisk zagrażających współczesnemu językowi polskiemu. Zagrożenia nie widziały tylko 4 osoby (niektóre z nich uzasadniały to w następujący sposób: "Język sam się obroni” czy „Język jest żywym organizmem, reagującym na zmiany”). 7 badanych pozostawiło puste miejsce $\mathrm{w}$ tym miejscu ankiety lub napisało: „Nie mam zdania”.

Poniżej zaprezentowana została lista zagrożeń dla języka polskiego według respondentów ankiety:

- Elementy obce (wtręty obcojęzyczne, obce/obcojęzyczne wyrazy/nazwy, wzorowane na językach obcych, naleciałości, wpływ języka angielskiego): 10

- Skróty (język skrótów, skracanie słów, skrótowy sposób wypowiedzi, skróty internetowe i SMS-owe): 10

- Komunikacja internetowa i SMS-owa (język internetowy, internet, komunikacja komputerowa, skróty internetowe/w SMS-ach): 9 
- Wulgaryzacja (wulgaryzmy, wulgarne słownictwo, przekleństwa): 7

- Niedbałość (niestaranność, prymitywizacja, pośpiech): 4

- Nowe wyrazy (neologizmy, wprowadzanie nowych wyrazów zamiast dawnych): 4

- Niewłaściwa nauka w szkole (złe programy nauczania, brak lekcji poświęconych poprawności językowej): 3

- Język młodzieży (slang młodzieżowy): 2

- Język polityków: 1

- Język reklamy: 1

- Język radia i telewizji: 1

- Ubożenie słownictwa: 1

- Zanik czytelnictwa: 1

- Zanik interpunkcji: 1

Wnioski:

Po analizie powyższych wyników nasuwa się przede wszystkim wniosek, że starsze osoby są w większości przekonane, iż język polski jest zagrożony. Czynniki zagrażające współczesnej polszczyźnie, które były wymieniane w odpowiedzi na to pytanie, w znacznej części są powtórzeniem odpowiedzi na pytanie 2. (dotyczące nowych zjawisk w języku polskim) bądź na pytanie 5. (na temat negatywnych zmian $\mathrm{w}$ języku polskim). Na czele zagrożeń - według ankietowanych - są trzy grupy zjawisk: wpływ języków obcych (zwłaszcza angielszczyzny), szerzenie się mowy „na skróty” oraz rozpowszechnienie się komunikacji elektronicznej (zwłaszcza internetowej). Do liczby wskazań pierwszego zjawiska można dodać liczbę odpowiedzi na temat nowych wyrazów (badani sugerowali, że chodzi o wyrazy obce), natomiast część odpowiedzi wymieniających skróty dotyczy komunikacji elektronicznej (badane osoby często dodawały, że chodzi im zwłaszcza o skróty w komunikacji internetowej i SMS-owej). Powyższe dane świadczą o tym, że dla osób starszych zalew polszczyzny przez elementy obce (zwłaszcza angielskie słownictwo) może być zagrożeniem dla bytu ich języka. Może z tym mieć związek rozwijająca się komunikacja elektroniczna, oparta właśnie na obcych wzorcach. Przejawia się $\mathrm{w}$ tym zatem pewien konserwatyzm ludzi starszych, widzących zagrożenie $\mathrm{w}$ nowych technologiach, burzących ich tradycyjny model języka i komunikacji językowej (opartych na żywej rozmowie czy na kontakcie $\mathrm{z}$ literaturą).

Według opinii wielu starszych osób zagrożeniem dla współczesnej polszczyzny jest jej wulgaryzacja. Zapewne chodzi tu nie o samo zagrożenie dla bytu języka, lecz raczej jego jakości. Tak też należy interpretować wskazania 
zagrożeń $\mathrm{w}$ postaci ubożenia słownictwa, zaniku czytelnictwa (a co za tym idzie - wzorców językowych z literatury) czy niedostatków w programach szkolnych.

W kontekście zagrożonej jakości można intepretować nieliczne wskazania dotyczące języka środowisk pewnych grup społecznych (wymieniono tu tylko język młodzieży i język polityków), instytucji (zob. język $\mathrm{w}$ radiu i telewizji) czy swoistych tekstów (język reklamy, język pisany bez interpunkcji).

Pytanie nr 9: Czy Pani/Pana zdaniem rozpowszechnione błędy językowe, takie jak przekonywujący (zamiast przekonujący), trwać nadal, $w$ cudzysłowiu (zamiast $w$ cudzysłowie) itp. można tolerować? (a. Tak, b. Nie, c. Nie mam zdania)

TAK: 11 głosów $(25,6 \%)$

NIE: $21(48,8 \%)$

NIE MAM ZDANIA: 10 (23,3\%)

INNE: 1 (osoba odpowiadająca napisała, że zależy to od rozmówcy)

\section{Wnioski:}

Pytanie nr 9 miało charakter sondy $\mathrm{w}$ sprawie stosunku do zjawisk uznawanych przez wydawnictwa poprawnościowe za błędy, choć występujących dość często w wypowiedziach współczesnych Polaków. Jak widać $\mathrm{z}$ wyników, prawie połowa badanych była przeciwna tolerancji dla rozpowszechnionych błędów językowych. Badane osoby starsze już we wcześniejszych częściach ankiety sygnalizowały zaniepokojenie szerzącymi się błędami we współczesnej polszczyźnie (zob. odpowiedzi na pytania 2, 5 i 8; w odpowiedziach na pytanie nr 5 ankietowani najczęściej wskazywali niepoprawność i niechlujność językową jako negatywne zjawisko we współczesnym języku polskim). W związku z tym spodziewać się można było takich właśnie wyników dotyczących ostatniego pytania ankiety.

Zwolennicy tolerowania niektórych błędów ( $\mathrm{w}$ tym wypadku rozpowszechnionych) byli w wyraźnej mniejszości (nieco ponad 1/4 badanych). Niemal tyle samo było osób niemających zdania w tej sprawie. Stosunek do zjawisk językowych sprzecznych z normą, ale powszechnych w użyciu jest zagadnieniem dyskusyjnym zarówno $w$ sferach językoznawczych, jak $\mathrm{i}$ w społeczeństwie, ma to więc $\mathrm{w}$ pewien sposób odzwierciedlenie w odpowiedziach badanych udzielonych na pytanie nr 9 . 
Warto zwrócić uwagę na średnią wieku badanych w grupach, opowiadających się za tolerancją błędów i jej przeciwnikami. Średnia wieku przeciwników tolerowania błędów (także rozpowszechnionych) to 68,3 lat, a więc powyżej średniej wszystkich osób uczestniczących w badaniu $(66,7)$. $\mathrm{Z}$ kolei średnia wieku tolerowania wspomnianych błędów to 65,8 lat, a więc niższa nie tylko od poprzedniej grupy, ale też od ogólnej średniej. Na podstawie tych danych można zatem przyjąć, że im starszy jest użytkownik języka, tym bardziej negatywnie nastawiony jest on do jakichkolwiek błędów językowych, natomiast młodsi użytkownicy (nawet $\mathrm{z}$ grupy badanych ludzi starszych) są bardziej liberalni w tej sprawie i skłonni do akceptowania niektórych błędów językowych.

\section{Podsumowanie}

Na podstawie wyników opartych na stosunkowo krótkim badaniu ankietowym, przeprowadzonym w niewielkiej grupie osób starszych, można dojść jednak do pewnych ogólnych wniosków na temat stosunku ludzi w podeszłym wieku do zagadnień związanych ze stanem współczesnego języka polskiego. Przede wszystkim widać, że ludzie starsi wykazują żywe zainteresowanie tym, co się dzieje w dzisiejszej polszczyźnie. Potwierdzają to wyniki ankiety, a także chętny udział respondentów w badaniu (niewiele było przykładów uchylania się od odpowiedzi na zadawane pytania).

Z przeprowadzonego badania wynika, że osoby starsze aktywnie reagują na aktualne zjawiska pojawiające się w języku. Są w stanie je wskazać, ocenić i skomentować. Natomiast wykazują oni mniejsze zainteresowanie przykładami z przeszłości języka polskiego i przypominają sobie mniej elementów językowych z dawnych lat. Można przypuszczać, że bardziej żyją oni teraźniejszością języka polskiego niż jego przeszłością.

Zmiany w polszczyźnie, przejawiające się nowymi zjawiskami, są przez ludzi starszych oceniane najczęściej negatywnie. Zmiany te - według nich mogą zagrozić naszemu językowi (przede wszystkim jego jakości). Szczególnie źle oceniane przez starsze osoby są szerzące się obcojęzyczne wtręty (zwłaszcza anglicyzmy), zastępowanie naturalnej komunikacji językowej przez komunikację elektroniczną oraz skrótowy sposób porozumiewania się (komunikowanie się „na skróty”).

$\mathrm{W}$ odpowiedziach dotyczących zmian w języku polskim osoby $\mathrm{w}$ podeszłym wieku reprezentują postawę konserwatywną, co nie powinno być zaskoczeniem. Wzorcem poprawnej i pięknej polszczyzny jest dla tych ludzi 
przede wszystkim literatura, ale także słowo płynące z ust osób duchownych. Negatywnie oceniany jest przez starszych ludzi język polski w masowych mediach (zwłaszcza w internecie i w telewizji). Ludzie starsi zdają się być mało tolerancyjni w kontekście popełnianych błędów językowych, nawet, jeśli są one w powszechnym użyciu.

Starsi ludzie wyrażają jednocześnie swoje zaniepokojenie obniżającym się - według nich - poziomem języka polskiego, coraz niższą jakością wypowiedzi i niedbałością użytkowników języka, stając się niejako orędownikami poprawności i jakości języka. W związku z tym cenią sobie szczególnie osoby propagujące $\mathrm{w}$ środkach masowego przekazu staranną, bezbłędną i piękną polszczyznę.

\section{BIBLIOGRAFIA}

Kaczorowska-Bray, K., Milewski, S. \& Michalik, M. (2020). Starość - jak ją widzi logopedia. Gdańsk: Wydawnictwo Uniwersytetu Gdańskiego.

Łuczyński, E. (2019). Dyslekt jako swoista odmiana biolektu, Poradnik Językowy, 2, s. 83-91.

Łuczyński, E. (2018). Miejsce języka ludzi starszych wśród odmian współczesnej polszczyzny. W: W. Tłokiński, S. Milewski, K. Kaczorowska-Bray (red.). Gerontologopedia. (ss. 108-138). Gdańsk: Harmonia.

Milewski, S., Kaczorowska-Bray, K. \& Kamińska, B. (2016). Późna dorosłość z perspektywy logopedii, Pogranicze. Studia Społeczne, XXVIII, s. 165-182.

Radkiewicz, M. \& Łazarewicz, M. (2018). Komunikacja ze starszymi osobami w kontekście relacji społecznych. W: W. Tłokiński, S. Milewski, K. Kaczorowska-Bray (red.). Gerontologopedia. (ss. 180-199). Gdańsk: Harmonia.

Rutkiewicz-Hanczewska, M. (2018). Wiek a nazywanie. Procesy wyszukiwania słów w starszym wieku. W: W. Tłokiński, S. Milewski, K. Kaczorowska-Bray (red.). Gerontologopedia. (ss. 241-26). Gdańsk: Harmonia.

Skubalanka, T. (1976). Założenia analizy stylistycznej. W: H. Markiewicz, J. Sławiński (red.). Problemy metodologiczne współczesnego literaturoznawstwa. (ss. 250-273). Kraków.

Świątek, A. (2007). Specyficzne zjawiska komunikacyjne w wieku senioralnym, Sztuka Leczenia, XIV, nr 1-2, s. 69-78.

Tłokiński, W. (1990). Mowa ludzi u schyłku życia. Warszawa: PWN.

Tłokiński, W., Milewski, S. \& Kaczorowska-Bray, K. (red.) (2018). Gerontologopedia. Gdańsk: Harmonia.

Wilkoń, A. (2000). Typologia odmian językowych współczesnej polszczyzny. Katowice: UŚ.

Wójcik-Topór, P. (2018). Starzenie się a język - wspomaganie komunikacji w wieku senioralnym. W: W. Tłokiński, S. Milewski, K. Kaczorowska-Bray (red.). Gerontologopedia. (ss. 227-240). Gdańsk: Harmonia.

Zaśko-Zielińska, M. (2009). Próba charakterystyki biolektu - język a wiek, Studia Linguistica, XXVIII, Wrocław, s. 117-123. 
